\section{多剤耐性 HIV}

2 剂以上の抗 HIV (human immunodeficiency virus) 薬に耐性を持つHIV。しかし，耐性の程度に関しての 判断は研究者により異なる。HIV 感染症の化学療法の 問題点は HIV が変異して薬剂耐性を獲得することであ る。現在, 我国で認可されている薬は核酸系逆転写酵素 阻害薬 (NRTI: nucleoside reverse transcriptase inhibitor), 非核酸系逆転写醩素阻害薬 (NNRTI: nonnucleoside reverse transcriptase inhibitor) とプロテ アーゼ阻害薬 (PI: protease inhibitor)の 3 種類である。 それぞれには数種類の薬剤がある。単剂投与では HIV が容易に耐性を獲得し治療が困難であった。1996 年頃, 2 種類またはそれ以上の RTI と PI を併用する多剤併用 療法(HAART)の開発により HIV 感染者の QOL (quality of life)が劇的に向上した。現在, HIV 感染症は完全治 癒はできないが「治療可能な慢性感染疾患」とされてい る。しかし，現在の多剤併用療法では投与したすべての 薬郕に耐性をもつ多剤耐性 HIV が発現しており，さら に優れた薬の開発が待たれている。作用機序が異なる第 3 , 第 4 の薬や既存薬の再設計により開発される新薬の 多剤併用療法で, 既感染細胞がすべて死滅するまでの長 期間にわたってウイルス増殖を完全に阻止することで 「完全治癒」が可能ではと期待されている。(大類 洋)

\section{オリゴチオフェン}

一般にオリゴマーという用語は「構成単位が 2 個から 20 個程度繰り返しつながった, 物理的性質がその構成 単位の増減で大きく変化するもの」と定義されている。 これに基づけば， 2 個から 20 個程度のチオフェン環が つながった化合物をオリゴチオフェンと呼び，さらに多 数のチオフェン単位の重合体をポリチオフェンと呼ぶこ とになろう。このようなチオフェンの重合体は，優れた 電気化学的特性を有し, 熱や光に対して安定で，千才 フェン環上の化学修飾が比較的容易であることなどか ら, 古くより導電性 $\pi$ 共役化合物として注目されてき た。オリゴチオフェンに扔いては，チオフェン環同士が $\alpha$-位で繰り返し結合した $\alpha$-オリゴチオフェンの研究例 が多く，合成法には塩化銅存在下での $\alpha$-リチオ体の酸 化的カップリングや遷移金属触媒を用いるクロス・カッ プリングなどがある。物理的性質に関しては，鎖長の伸 長に伴って 20 量体まで変化することが，UV 吸収スぺ クトルや蛍光スペクトルなどの光学特性の評価によって 明らかにされている。構造が明確な $\alpha$-オリゴチオフェ ンについては最近, 電解効果トランジス夕素子やエレク トロルミネッセンス素子など，様々なエレクトロニクス 材料への応用研究も活発である。

(土本晃久)

\title{
還元的カップリング
}

還元的カップリングとは，主にアルデヒドやケトン， およびイミンの還元的二量化による1,2-ジオール，ジ アミンの生成反応のことをいう。通常, $\mathrm{Na}, \mathrm{Mg}, \mathrm{Al}$, $\mathrm{Zn}, \mathrm{Mn}$ のような金属還元剂が用いられる。

本反応は，金属からカルボニル基へ一電子移動し，ケ チルラジカル（ラジカルアニオン）が生成し，次に，ヶ チルラジカルが二量化することで $1,2-$ 洔ールジアニ オンとなった後に，プロトン化されてジオールが生成す る。

近年，本反応を立体選択的に進行させるために，還元 凰としてへテロ原子に対する親和性の高いチタン，バナ ジウムなどの低原子価錯体や希土類錯体がよく用いられ ており，生理活性を持つ天然物合成に扔けるジオールの 導入法としても活用されている。さらに，触媒的，かつ エナンチオ選択的な 1，2-ジオールの合成法も盛んに研 究されている。

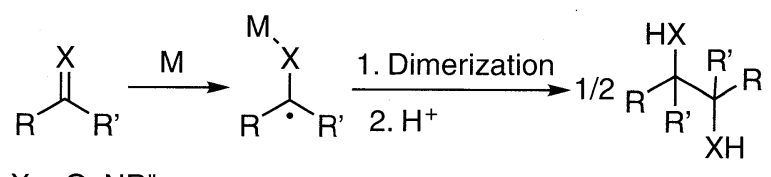
$X=O, N R^{\prime \prime}$

(谷口暢一)

\section{路}

\section{exo 型, endo 型グリコシダーゼ}

グリコシダーゼは糖鎖をアノメリック位で加水分解す る酵素であるが，大きくexo 型と endo 型に分類され る。exo 型グリコシダーゼは糖鎖の末端部から一定数ご とに規則正しく加水分解, 一定の低級糖を生産す万。反 応は非還元末端で起きるものがほとんどである。分解に よって生産される低級糖は単糖とは限らず，たとえば $\beta$-アミラーゼでは 2 糖であるマルトースを生産する。 一方, endo 型グリコシダーゼは糖鎖内部グリコシドを ランダムに加水分解し, 高分子多糖の粘度を急速に低下 させる。果実は熟すことによりやわらかくなるが，これ は endo 型グリコシダーゼによって細胞壁の構成成分で あるペクチン（ガラクツロン酸およびそのメチルエステ ル体が 1, 4- $\alpha$ グリコシド結合で高度に重合したへテロ多 糖）が分解されるためである。でん粉（アミロース）を 分解するアミラーゼの場合, その歴史的経緯から,

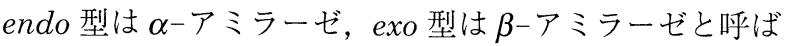
れることが多い。

(橋本 勝) 